University of Nebraska - Lincoln

DigitalCommons@University of Nebraska - Lincoln

Papers in the Earth and Atmospheric Sciences

Earth and Atmospheric Sciences, Department

4-2013

\title{
Responses of microbial phototrophs to late-Holocene environmental forcing of lakes in south-west Greenland
}

Nina S. Reuss

University of Copenhagen,,nreuss@bio.ku.dk

N. J. Anderson

Loughborough University, N.J.Anderson@lboro.ac.uk

Sherilyn C. Fritz

University of Nebraska-Lincoln, sfritz2@unl.edu

Gavin L. Simpson

University College London, gavin.simpson@ucl.ac.uk

Follow this and additional works at: https://digitalcommons.unl.edu/geosciencefacpub

Reuss, Nina S.; Anderson, N. J.; Fritz, Sherilyn C.; and Simpson, Gavin L., "Responses of microbial phototrophs to late-Holocene environmental forcing of lakes in south-west Greenland" (2013). Papers in the Earth and Atmospheric Sciences. 384.

https://digitalcommons.unl.edu/geosciencefacpub/384

This Article is brought to you for free and open access by the Earth and Atmospheric Sciences, Department of at DigitalCommons@University of Nebraska - Lincoln. It has been accepted for inclusion in Papers in the Earth and Atmospheric Sciences by an authorized administrator of DigitalCommons@University of Nebraska - Lincoln. 


\title{
Responses of microbial phototrophs to late-Holocene environmental forcing of lakes in south-west Greenland
}

\author{
Nina S. Reuss, ${ }^{1}$ N. John Anderson, ${ }^{2}$ Sherilyn C. Fritz, ${ }^{3}$ and Gavin L. Simpson ${ }^{4}$
}

1. Freshwater Biological Laboratory, Department of Biology, University of Copenhagen, Hillerød, Denmark

2. Department of Geography, Loughborough University, Loughborough, U.K.

3. Department of Geosciences and School of Biological Sciences, University of Nebraska, Lincoln, NE, U.S.A. 4. Department of Geography, University College London, London, U.K.

Corresponding author - Nina S. Reuss, Freshwater Biological Laboratory, Department of Biology, University of Copenhagen, Helsingørsgade 51, DK-3400 Hillerød, Denmark; email nreuss@bio.ku.dk

\begin{abstract}
1. The biological structure of arctic lakes is changing rapidly, apparently in response to global change processes such as increasing air temperatures, although altered nutrient stoichiometry may also be an important driver. Equally important, however, are local factors (e.g. landscape setting, hydrological linkages and trophic interactions) that may mediate responses of individual lakes at the regional scale. Despite general acknowledgement of the importance of local factors, there has been little focus on among-lake variability in the response to environmental change.

2. Sedimentary pigments, organic carbon and nitrogen, and biogenic silica (BSi) in ${ }^{210} \mathrm{~Pb}$ and ${ }^{14} \mathrm{C}$-dated sediment cores from three contrasting lakes in the Kangerlussuaq area $\left(c .67^{\circ} \mathrm{N}, 51^{\circ} \mathrm{W}\right)$ of south-west Greenland were used to reconstruct algal and phototrophic bacterial ecological change during the late-Holocene. Water chemistry for the individual lakes varies in terms of conductivity (range: 30$3000 \mu \mathrm{Sm}^{-1}$ ) and stratification regimes (cold monomictic, dimictic and meromictic), linked with their position along the regional climate gradient from the coast and to the present ice sheet margin.

3. Despite essentially similar regional climate forcing over the last $c .1000$ years, marked differences among lake types were observed in the phototrophic communities and their temporal variability. Considerable short-term variability occurred in an oligosaline, meromictic lake (SS1371), dominated by purple sulfur bacterial pigments, most likely due to a tight coupling between the position of the chemocline and the phototrophic community. Communities in a lake (SS86) located on a nunatak, just beyond the edge of the present ice sheet shifted in a nonlinear pattern, approximately $1000 \mathrm{cal}$. years BP, possibly due to lake-level lowering and loss of outflow during the Medieval Climate Anomaly. This regime shift was marked by a substantial expansion of green sulfur bacteria.

4. A dilute, freshwater coastal lake (SS49) dominated by benthic algae was relatively stable until ca. $1900 \mathrm{AD}$ when rates of community change began to increase. These changes in benthic algal pigments are correlated with substantial declines $\left(1.3-0.44 \%\right.$ o) in $\delta^{15} \mathrm{~N}$ that are indicative of increased deposition of atmospheric inputs of industrially derived NOx into the atmosphere.

5. Climate control on lake ecosystem functioning has been assumed to be particularly important in the Arctic. This study, however, illustrates a complex spatial response to climate forcing at the regional scale and emphasizes differences in the relative importance of changes in the mass ( $m$, both precipitation and nutrients) and energy flux (E) to lakes for the phototrophic community structure of lowarctic Greenland lakes.
\end{abstract}

Keywords: Arctic, biogenic silica, energy and mass, nitrogen, pigments 


\section{Introduction}

Arctic ecosystems are changing rapidly in response to global change processes (Overpeck et al., 1997; Post et al., 2009). Much of the evidence for altered biological structure in arctic lakes over the last $50-150$ years is derived from the natural archives recorded in lake sediment (Smol et al., 2005). Considerable emphasis has been placed on increased air temperature at high latitude and its impact on lake thermal budgets as a driver of these observed changes (Smol et al., 2005) but other global change processes, such as increased regional N-deposition are undoubtedly important (Bergström, Blomqvist \& Jansson, 2005; Wolfe, Cooke \& Hobbs, 2006). While these large-scale, hemispheric processes impact on lake functioning, indirect effects (largely mediated through catchment processes such as soil development, vegetation succession, altered nutrient cycling and hydrology) can have profound impacts on lakewater chemistry and biological structure (Kane et al., 1992; Battarbee, 2000; Engstrom et al., 2000). The effect of these direct and indirect fluxes of mass and energy on lake response to climate has been highlighted in a conceptual model developed by Leavitt et al. (2009). This model indicates the extent to which direct climate impacts on lakes have to be balanced by consideration of catchment-mediated fluxes of mass ( $m$ - water, solutes, and particles) and energy [E - e.g. irradiance (PAR, UVR), wind friction, or transfer of atmospheric heat]. This balance may be very important in the Arctic where precipitation is often very low, nutrients are limiting, and there is a strong seasonality of energy inputs (Vincent, Hobbie \& Laybourn-Parry, 2008).

Much of the evidence for change within lake communities in the Arctic has focused on diatoms, but there is also some evidence for altered food web dynamics (Quinlan, Douglas \& Smol, 2005) and increased lake productivity derived from reflectance spectroscopy (Michelutti et al., 2005). While diatoms are an important component of arctic lake ecosystems, non-siliceous algae also can be significant (Vadeboncoeur et al., 2003; Bonilla, Villeneuve \& Vincent, 2005). Pigments are produced by algae and other phototrophic organisms, some of which are taxonomically specific while others are ubiquitous in most algal groups (Jeffrey, Mantoura \& Wright, 1997). Therefore, pigment analysis by high-performance liquid chromatography (HPLC) provides important information about a wide range of primary producers and phototrophic bacteria and hence whole-lake responses to environmental forcing (Leavitt \& Hodgson, 2001). Analysis of sedimentary pigments is now an important component of paleolimnological studies (Vine- brooke et al., 1998; Leavitt et al., 1999; Leavitt \& Hodgson, 2001) but their application to arctic lakes has been relatively limited (Pienitz et al., 2000; Anderson et al., 2008; Reuss et al., 2010a,b). In a pigment study of two oligosaline lakes in south-west (SW) Greenland, McGowan, Juhler \& Anderson (2008) highlighted the individual and nonlinear response of lakes to climate forcing at centennial timescales, perhaps due to differences in lake morphometry and benthic-pelagic productivity. Here we use pigment analysis to address recent ecological change in lake phototrophic communities (i.e. algae and phototrophic bacteria).

Focusing on three lakes positioned along the regional climate gradient in the Kangerlussuaq area of SW Greenland and with very different hydrological budgets, conductivity and stratification regimes, we evaluate the degree of spatial variability in the extent to which algal and phototrophic bacterial responses to late-Holocene climate change in this area are mediated by changing fluxes in mass $(m)$ and energy (E) (sensu Leavitt et al., 2009). Closed-basin lakes with increased ion concentration and strong stratification are expected to respond strongly to direct effects of mass and energy flux determining changes in effective moisture (Battarbee, 2000; Leavitt et al., 2009). Previous work on this lake type in the Kangerlussuaq area suggests that the over-riding effect on lake functioning is via direct mass transfer, that is, the impact of hydrological fluxes on lake levels (McGowan, Ryves \& Anderson, 2003; Aebly \& Fritz, 2009; Leavitt et al., 2009). In contrast, dilute freshwater lakes in this area are more affected by indirect changes in mass flux mediated by the specific catchment properties (Anderson et al., 2008; Heggen, Birks \& Anderson, 2010).

\section{Methods}

\section{Study sites}

Kangerlussuaq (Søndre Strømfjord in Danish) is a 150-km-long glacial fjord in SW Greenland (Figure 1), and the area between the coast and the ice sheet is the widest ice-free land area in Greenland today (c. $180 \mathrm{~km})$. There are thousands of lakes that are well suited for paleoclimatic investigations and direct anthropogenic influence is minimal (Anderson et al., 2001); however, as with the majority of arctic lakes, they are impacted by northern hemisphere atmospheric pollution (Bindler et al., 2001). The area encompasses a strong climatic gradient from the inland continental climate to a more maritime environment at the coast. Annual precipitation at Kangerlussuaq town at the head of the fjord is $<150 \mathrm{~mm}_{\text {year }}{ }^{-1}$, while precipitation at the coast is 


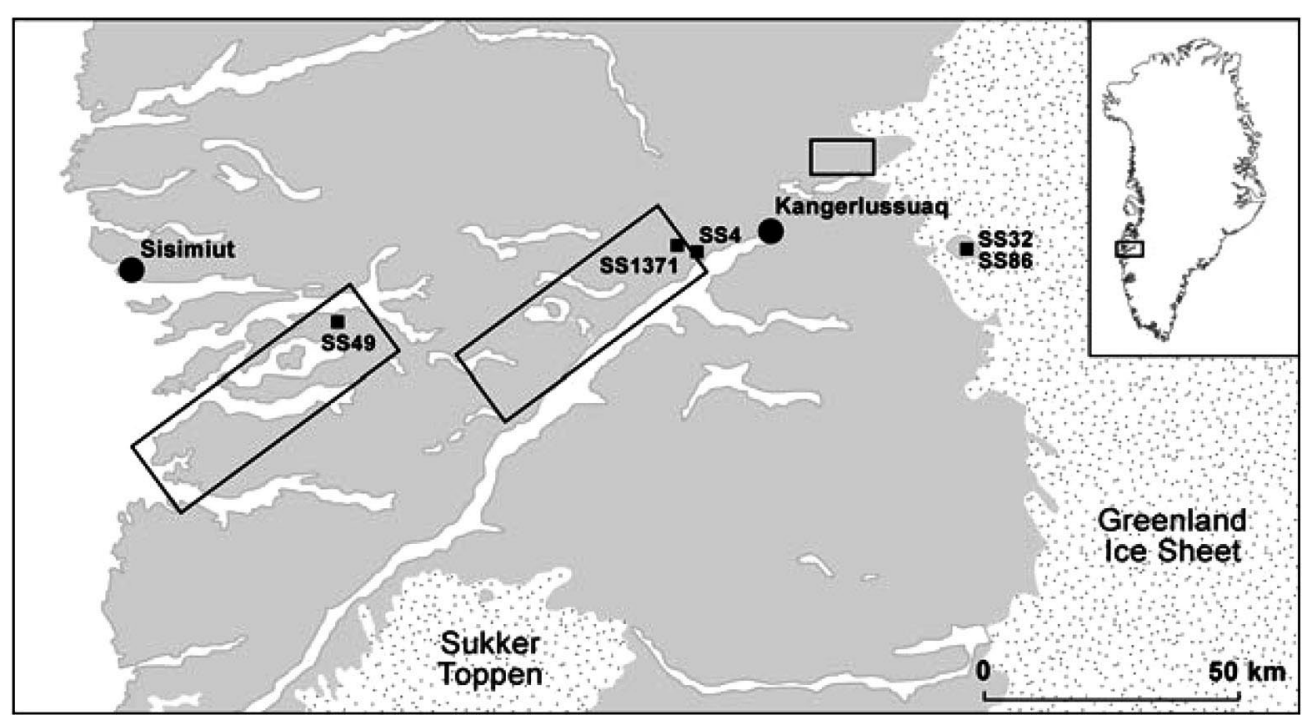

Figure 1. Location of the study sites (SS49, SS1371, SS86) along the Kangerlussuaq fjord (south-west Greenland) on a transect from the sea to the ice sheet margin, together with the location of two additional lakes referred to in the text (SS4, SS32; see Table 1). The rectangles indicate the approximate location of the three lake groups referred to in Table 1 (coastal, central, ice margin) for comparative purposes.

$>500 \mathrm{~mm}$ year $^{-1}$. The annual temperature range is greatest at Kangerlussuaq town with average summer/winter temperatures of $10 /-18{ }^{\circ} \mathrm{C}$ compared to $6 /-12{ }^{\circ} \mathrm{C}$ at the coast. Estimated evaporation at the head of the fjord is c. $300 \mathrm{~mm}$ and together with the low precipitation results in negative effective precipitation in the area extending to approximately half way $(80 \mathrm{~km})$ to the coast from the ice sheet margin (Hasholt \& Søgaard, 1978). Groundwater flows are minimal in SW Greenland due to permafrost.

An extensive study of 86 lakes from the Kangerlussuaq area along a transect from the ice sheet to the coast identified the main characteristics of lake chemistry (Anderson et al., 2001). The majority of the lakes are dilute $\left(<300 \mu \mathrm{S} \mathrm{cm}^{-1}\right)$, with an mean conductivity of $160 \mu \mathrm{S} \mathrm{cm} \mathrm{cm}^{-1}$ while the remaining (ca. 10\%) of the lakes are oligosaline, have conductivity $>800 \mu \mathrm{sm}^{-1}$ and are characterized by $\mathrm{Na} \mathrm{Mg}-\mathrm{CO}_{3}$ chemistry (Anderson et al., 2001). These oligosaline lakes (Williams, 1991) are situated well above the marine limit and cannot therefore have been formed by trapping of marine water due to isostatic uplift, which is a common method of oligosaline lake formation in the Arctic and Antarctic (Burton, 1981; Ouellet et al., 1987). The primary cause of elevated salinity in these saline closed-system lakes is most likely evaporation enhanced by inputs of salts from nearby terrestrial sources, brought to the lakes by aeolian activity (Anderson et al., 2001; Willemse et al., 2004).

Details of the physical and chemical characteristics of the three study lakes are given in Table 1 . The study lakes are representative of the range of water chemistry (fresh- oligosaline), DOC concentration and thermal stratification (cold monomictic, dimictic and meromictic) found in the Kangerlussuaq area (see Table 1) (Anderson et al., 2001). The lakes are also spatially separated along the geographic gradient from the coast to the inland ice (Figure 1). Lake SS49 is located c. $120 \mathrm{~km}$ to the west of the ice sheet at $340 \mathrm{~m}$ a.s.l. and is typical of the dilute oligotrophic lakes $\left(<50 \mu \mathrm{S} \mathrm{cm}^{-1}\right.$; DOC $\left.4.8 \mathrm{mg} \mathrm{L}^{-1}\right)$ found along the coastal margin (Anderson et al., 2001; Anderson \& Stedmon, 2007). SS1371 located c. $45 \mathrm{~km}$ west of the ice sheet is an oligosaline closed-basin lake, surrounded by extensive fossil shorelines indicative of substantially higher lake levels in the past. SS86 is located on a nunatak, an isolated mountain top that protrudes over the surface of the ice sheet, c. $5 \mathrm{~km}$ inside the ice sheet and has significantly higher conductivity and alkalinity compared to both a neighboring lake (SS32, Table 1) and to other freshwater lakes in the Kangerlussuaq area (Anderson et al., 2001). SS86 and SS1371 are fishless but sticklebacks ( $\mathrm{Ga}$ teus sp.) were observed in SS49.

\section{Sediment coring}

Sediment cores (22-34 cm in length) were collected in April 2000 by freeze-coring, which results in cores with an undisturbed surface layer. The sediments from SS1371 and SS86 were laminated, whereas the core from SS49 had no visible laminations. The cores were shipped to the laboratory frozen and wrapped in black plastic to limit light and oxygen access. Cores were stored undisturbed at $-20^{\circ} \mathrm{C}$ in the dark until sectioning. Sectioning 
Table 1. Mean morphological and water chemistry characteristics of the lakes shown in Figure 1 and other sites referred to in the text (SS32, SS4)

\begin{tabular}{|c|c|c|c|c|c|c|c|c|c|}
\hline & \multirow[b]{3}{*}{ Units } & & & & \multicolumn{5}{|c|}{$\underline{\text { Study lakes }}$} \\
\hline & & \multicolumn{3}{|c|}{ Mean chemistry - lake groups } & Coastal & Oligosaline & \multicolumn{3}{|c|}{ Nunatak } \\
\hline & & Coastal & $\begin{array}{r}\text { Central: } \\
\text { head of fjord }\end{array}$ & $\begin{array}{r}\text { Ice } \\
\text { margin }\end{array}$ & SS49 & SS1371 & SS86 & SS32 & SS4 \\
\hline Latitude & ${ }^{\circ} \mathrm{N}$ & 66.77 & 66.97 & 67.05 & 66.86 & 67.06 & 66.96 & 66.97 & 66.99 \\
\hline Longitude & ${ }^{\circ} \mathrm{W}$ & 52.67 & 51.26 & 50.33 & 52.66 & 51.13 & 49.81 & 49.8 & 51.04 \\
\hline Altitude & $\mathrm{m}$ & 240.6 & 257.6 & 394.1 & 320 & 150 & 470 & 470 & 170 \\
\hline $\mathrm{pH}$ & & 7 & 7.9 & 7.6 & 6.63 & 8.8 & 8.26 & 7.3 & 9 \\
\hline Cond. & $\mu S \mathrm{~cm}^{-1}$ & 50 & 298.3 & 119.2 & 26.7 & 3080 & 323 & 48 & 2540 \\
\hline $\mathrm{TN}$ & $\mu g \mathrm{~L}^{-1}$ & 208 & 717.8 & 455.6 & 143.3 & 2150 & 587 & 308 & 803 \\
\hline $\mathrm{TP}$ & $\mu \mathrm{g} \mathrm{L}^{-1}$ & 4.3 & 6.8 & 8 & 3.7 & 14 & 3.6 & 5 & 9 \\
\hline $\mathrm{Ca}$ & $\mu \mathrm{eq} \mathrm{L}^{-1}$ & 225.2 & 1257.4 & 416.8 & 123 & 3422 & 1256 & 215 & 1194 \\
\hline $\mathrm{Mg}^{2+}$ & $\mu \mathrm{eq} \mathrm{L}^{-1}$ & 113.7 & 1012.1 & 490.3 & 48 & 14227 & 1956 & 233 & 13,544 \\
\hline $\mathrm{Cl}$ & $\mu \mathrm{eq} \mathrm{L}^{-1}$ & 138.7 & 702.3 & 131.2 & 102 & 26150 & 498 & 55.7 & 12,515 \\
\hline DOC & $\mathrm{mg} \mathrm{L}^{-1}$ & 4.8 & 53.8 & 9.2 & 4.8 & 83 & 30.7 & 7.6 & 90 \\
\hline
\end{tabular}

For comparative purposes the mean water chemistry of three groups of lakes located along the fjord are given (Figure 1) (see Anderson et al., 2001; Pla \& Anderson, 2005 for details). The formal name for SS4 is Braya Sø.

was conducted in a cold room at less than $-10^{\circ} \mathrm{C}$ by removing the outer layers of the core with a wood planer and cutting into $0.5-\mathrm{cm}$ sections using a band saw. The samples were then cleaned with a glass plate and stored at $-80^{\circ} \mathrm{C}$ until freeze-drying and extraction of pigments.

\section{Sediment chronology}

Cores were dated by means of ${ }^{210} \mathrm{~Pb}$ (Figure 2), determined using gamma assay (Appleby et al., 1986) and bulk AMS ${ }^{14} \mathrm{C}$ were determined for selected depths on Russian cores taken at the same time as the freeze cores and within $2 \mathrm{~m}$ of the freeze core location. The Russian and freeze cores were readily cross-correlated using distinctive carbon profiles (total carbon or organic carbon wt $\%$, see Figure 3).

\section{Pigment analyses}

About 0.1-0.5 g of homogenized freeze-dried sediment was extracted in $5 \mathrm{~mL}$ cold $100 \%$ acetone and spiked with an appropriate amount of internal standard $\beta$-apo8-carotenal (25-100 $\mu \mathrm{l})$. The mixture was sonicated, extracted overnight at $-20{ }^{\circ} \mathrm{C}$, filtered and diluted to a final concentration of $80 \%$ acetone to increase peak resolution before run by HPLC (Reuss \& Conley, 2005). Quantitative analyses of all pigments were conducted on a Shimadzu HPLC equipped with an on-line photodiode array detector (SPD-M10Avp) for quantifica- tion and fluorescence detector (RF-10Axl) for identification purposes only. The run method was a modification of Wright et al. (1991) as described by Reuss \& Conley (2005).

Tentative identification of individual pigments was based on a combination of retention times and absorption spectra. The quality of the absorption spectra diminished down core for some pigments, and identification was then primarily based on the retention time. Reference absorption spectra for identification and quantification of algal pigments were obtained from a single run of standards from DHI Water and Environment, Denmark and Jeffrey et al. (1997). Absorption spectra of bacterial pigments were obtained from a standard of okenone provided by A. Lami (CNR.ISE, Italy) and a culture of a green sulfur bacterium Chlorobium phaeobacteroides containing bacteriochlorophyll-e provided by R. Cox (University of Southern Denmark, Denmark). Concentrations of b-chlorophyll-e and okenone standards were determined at absorbance maxima using specific molar extinction coefficients $(467 \mathrm{~nm}$, $10 \times 10^{4} \mathrm{~L} \mathrm{mmol}^{-1} \mathrm{~cm}^{-1}$ (Frigaard, Larsen \& Cox, 1996), and $487 \mathrm{~nm}, 13.4 \times 10^{4} \mathrm{~L} \mathrm{mmol}^{-1} \mathrm{~cm}^{-1}$ (Züllig, 1985), respectively). Quantification of chlorophyll-a (chl-a) and pheopigment-a's (ppn-a) was conducted at $666 \mathrm{~nm}$, while carotenoids, chlorophyll-b, pheopigment- $b$ 's and bacteriochlorophylls were quantified at $449 \mathrm{~nm}$. Normalization of concentrations of all samples was con- 

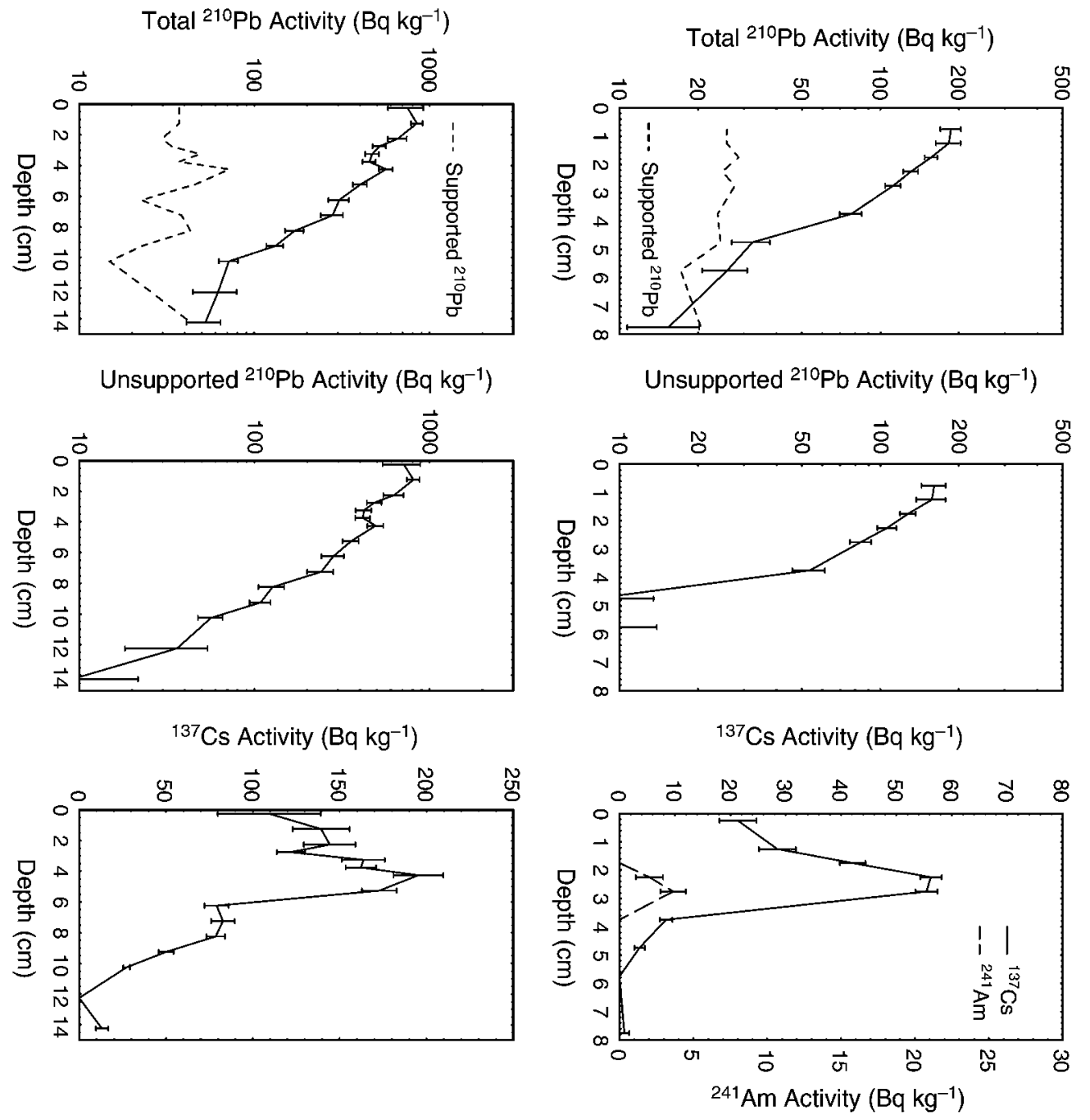

Figure 2. ${ }^{210} \mathrm{~Pb}$ and ${ }^{137} \mathrm{Cs}$ profiles for SS49 (left) and SS86 (right). Uppermost panels are total and supported ${ }^{210} \mathrm{~Pb}$ activity; the central panels are unsupported ${ }^{210} \mathrm{~Pb}$; the lowermost plots show the ${ }^{137} \mathrm{Cs}$ and ${ }^{241} \mathrm{Am}$ at SS86, the latter indicating the well-resolved radionuclide profiles despite the low sedimentation rates.

ducted by scaling to the highest value of the internal standard, $\beta$-apo-8-carotenal, except for the top half of the core from SS86 where the bacteriochlorophylls interfered with the internal standard peak. The ratio of chla/ppn-a was calculated to provide a simple preservation index as chlorophyll-a is readily degraded while its degradation products are much more stable. Three samples from lake SS49 were excluded from the data set due to a very irregular injection peak and chromatogram.

\section{Carbon, nitrogen, biogenic silica and stable isotope $\left({ }^{15} N\right)$ analyses}

Carbon $(\mathrm{C})$ and nitrogen $(\mathrm{N})$ content were determined using a CHNS elemental analyzer (CE instruments EA1110). The total fraction of $\mathrm{C}$ and $\mathrm{N}$ was measured on freeze-dried samples, while the inorganic C-fraction was measured on combusted samples $\left(2 \mathrm{~h}\right.$ at $\left.500{ }^{\circ} \mathrm{C}\right)$ and corrected for loss of organic mass. Organic $\mathrm{C}$ was calculated as the difference between the total and inorganic fraction. Biogenic silica (BSi) analyses were carried out on every or every other level in SS86, SS49 and SS1371. BSi was measured using the DeMaster (1981) method as modified by Conley \& Schelske (2001). Quality control of BSi analyses was carried out with reference samples used in an international inter-laboratory comparison (Conley, 1998) and 10\% duplicate samples. Samples for ${ }^{15} \mathrm{~N} /{ }^{14} \mathrm{~N}$ from SS49 were analyzed at the UC Davis Stable Isotope Facility, California, U.S.A. on Hydra 20-20 or Anca-GSL isotope ratio mass spectrometers. Freeze-dried subsamples of sediment were milled to a fine powder using a Retsch mixer mill. Approximately $0.001 \mathrm{~g}$ of milled sediment was transferred to pre-weighed tin capsules, which were then sealed. The 


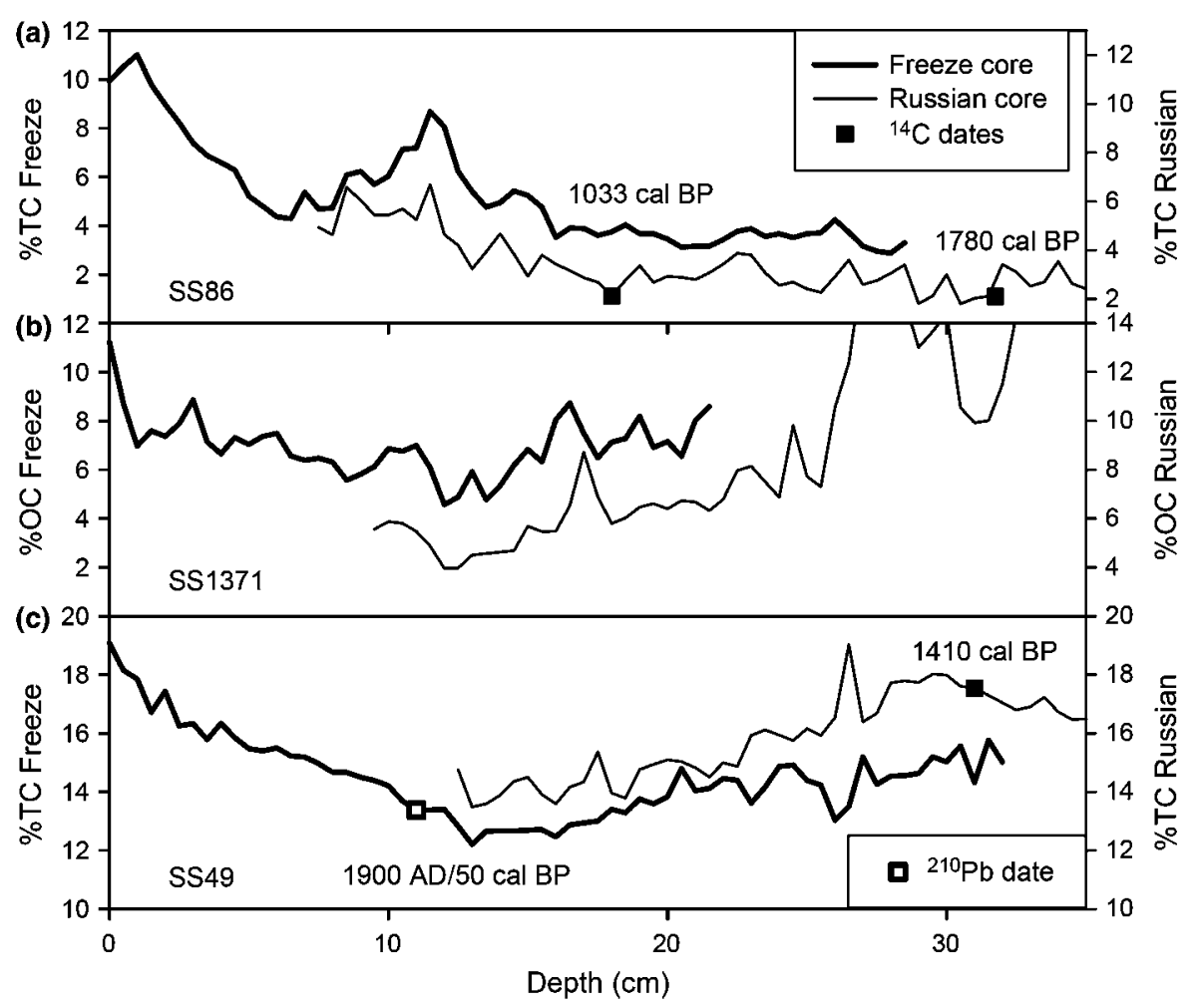

Figure 3. Cross-correlation of freeze and Russian cores. (a) SS86 (Nunatak lake), (b) SS1371 (oligosaline lake), (c) SS49 (coastal lake). ${ }^{14} \mathrm{C}$ dates used for constructing an age-depth curve are included in (a), while it falls outside the range of the plot in (b) $\left(44.5 \mathrm{~cm}=1270 \mathrm{cal} \mathrm{BP}\right.$, for further details of the ${ }^{14} \mathrm{C}$ date see $\mathrm{D}^{\prime}$ Andrea et al., 2011). In (c), the bottom ${ }^{210} \mathrm{~Pb}$ date and one of two ${ }^{14} \mathrm{C}$ dates is included in the plot although only the period covered by ${ }^{210} \mathrm{~Pb}$ is referred to in the discussion (see text). For details of the ${ }^{14} \mathrm{C}$ dates see Perren et al. (2012). No correction of potential reservoir effect was undertaken for the ${ }^{14} \mathrm{C}$ dates. Note that SS1371 is correlated by \%OC (organic carbon) not \% TC (total carbon) as there was significant amount of inorganic carbon in the sediment from this lake.

isotopic ratio of ${ }^{15} \mathrm{~N} /{ }^{14} \mathrm{~N}$ is expressed using the delta $(\delta)$ notation in parts per thousand (or per mille, \%o), where $\delta^{15} \mathrm{~N}(\%)=\left[\left(\mathrm{R}_{\text {sample }} / \mathrm{R}_{\text {standard }}\right)-1\right] \times 1000$, and $\mathrm{R}$ is the ${ }^{15} \mathrm{~N} /{ }^{14} \mathrm{~N}$ ratio in the measured sample or the appropriate standard. The standard for nitrogen is the $\delta^{15} \mathrm{~N}$ of atmospheric nitrogen (commonly referred to as AIR).

\section{Statistical analyses}

To summarize changes occurring in the sediment pigment composition in the three lakes over time, principal component analysis (PCA) was undertaken using CANOCO for Windows version 4.5 (Biometris - Plant Research International, Wageningen, The Netherlands). The analyses were based on $\log _{10}(x+1)$ transformed pigment concentrations, which were centered and standardized prior to analysis. Bacterial chlorophyll-e homologs and their degradation products were grouped into total Bchl-e and Bppn-e before analysis of lake SS86. Because of possible uncertainties in the sediment chronologies, only visual comparisons between the PCAaxis 1 scores and the independent proxies for global en- vironmental change (ice-core temperature inferences, effective precipitation) were undertaken.

\section{Results}

\section{Sediment chronology}

The cores used in this study cover a period of approximately $600-1600$ years. Unsupported ${ }^{210} \mathrm{~Pb}$ activities declined more or less exponentially with depth in SS86 and SS49 (Figure 2). At SS86, total ${ }^{210} \mathrm{~Pb}$ activity reached equilibrium with the supporting ${ }^{226} \mathrm{Ra}$ at a depth of around $5 \mathrm{~cm}$ and at SS49 at $14 \mathrm{~cm}$ (Figure 2). ${ }^{137} \mathrm{Cs}$ activity had a relatively well-resolved peak between 2.5$2.75 \mathrm{~cm}$ at SS86 and at SS49 at 4.5-5.5 cm. The presence of a clear ${ }^{241} \mathrm{Am}$ peak around $2.5-2.75 \mathrm{~cm}$ at SS86 (Figure 2) provided further support for allocating a bombtesting date (1963) to these levels. Application of the CRS dating model (Appleby \& Oldfield, 1978; Appleby, 2001), to the unsupported ${ }^{210} \mathrm{~Pb}$ data, constrained by the ${ }^{137} \mathrm{Cs}$ profiles, suggested a sediment accumulation of c. $0.11 \mathrm{~cm}_{\text {year }}{ }^{-1}$ over the last $c .100$ years at lake SS49. At SS86 the CRS model again indicated a relatively uni- 
form sediment accumulation rate with $5.25 \mathrm{~cm}$ depth dating to $c$. 1880 . At SS86 the final chronology was determined using the ${ }^{210} \mathrm{~Pb}$ chronology and extrapolation of simple linear regression of the ${ }^{14} \mathrm{C}$ dates (Figure 3). At SS49 only the environmental changes that occur within the period of ${ }^{210} \mathrm{~Pb}$ activity are discussed in detail in the present study, while chronological control below $11 \mathrm{~cm}$ is based on simple linear regression of ${ }^{14} \mathrm{C}$ dates (see Figure 3 and Perren et al., 2012 for details of the ${ }^{14} \mathrm{C}$ dates used).

${ }^{210} \mathrm{~Pb}$ activity at SS1371 was very low and irregular (P. G. Appleby, pers. comm.), possibly due to the extreme chemical environment of this permanently anoxic basin. As a result, the chronology for the freeze core is based on extrapolation of the ${ }^{14} \mathrm{C}$ chronology using a simple linear regression fitted to the ${ }^{14} \mathrm{C}$ date and sediment surface (c. $2000 \mathrm{AD}$ ) (see Figure 3 and D'Andrea et al., 2011 for details of the ${ }^{14} \mathrm{C}$ date used).

\section{Carbon, nitrogen and biogenic silica}

All three lakes showed changes in organic carbon (OC) content of c. $8 \%$ and in nitrogen (TN) content of c. 1\% over time resulting in conspicuous changes in the molar OC/TN ratio with a decline towards the present in SS49 and SS1371, while a very irregular profile was observed in SS86 (Figure 4). The low-conductivity coastal site (SS49) had a relatively high OC content, 12-19 wt\% with a decrease from the base of the core to $c .13 \mathrm{~cm}$ and a subsequent increase to the top. An increase in TN content towards the top was reflected in a decrease in the molar OC/TN ratio particularly in the top $10 \mathrm{~cm}$. The oligosaline lake, SS1371, and the nunatak lake, SS86, had lower organic carbon content, 4-12 and 3-11 $\mathrm{wt} \%$, respectively (Figure 4). The TN profile at SS86 increased from $c .7 \mathrm{~cm}$ to the top, while marked changes in the molar OC/TN ratio was observed between 13 and $5 \mathrm{~cm}$.

Biogenic silica content exhibited differences of an order of magnitude between the three lakes (Figure 4). At SS49, the BSi content was high throughout the core (12$22 \mathrm{wt} \%)$, indicating high diatom abundance, while it was low (1-2.4 wt\%) at SS1371 possibly due to silica dissolution. At SS86, BSi was more variable with highest values (3-5 wt\%) in the bottom part of the core.

\section{Sediment pigment record}

Different pigments dominated in the three study lakes and their concentrations differed by an order of magnitude between the relatively dilute lakes (SS49 and SS86) and the oligosaline lake (SS1371) (Figure 4). Although chlorophyll-a, chlorophyll-b and fucoxanthin are labile compounds, the remainder of the pigments are rela- tively stable once incorporated into the sediment record. Pigments at the costal lake SS49 (Figure 4a) indicated dominance of chromophyte algae (fucoxanthin, diatoxanthin, diadinoxanthin-like), as well as the presence of green algae and higher plants (lutein, pheophytin-b) and cyanobacteria (canthaxanthin, echinenone). The labile pigments, chlorophyll-a and fucoxanthin, increased towards the top of the core. All other pigments had relatively uniform profiles throughout the core. The preservation indicator, chlorophyll-a/pheophytin-a (chl-a/ ppn-a) ratio, indicated that no major changes in preservation conditions had occurred throughout the period covered by the core, except for significantly increased preservation (or more likely incomplete degradation) of the labile chlorophyll-a in the top few $\mathrm{cm}$. These changes were reflected in the ordination of the pigments that showed clustering of all samples except for the top samples that diverged from the rest.

The dominant pigment at the oligosaline lake SS1371 was okenone, which increased towards the core top (Figure $4 \mathrm{~b}$ ) and is specific to phototrophic purple sulfur bacteria, which require photic zone anoxia to thrive (Pfennig, 1989). Generally high but fluctuating concentration of all pigments and high values of the preservation indicator (chl-a/ppn-a) indicated that preservation at this site was good, in accordance with the inferred anoxic conditions due to presence of the anoxygenic phototrophic bacteria. The algal pigments indicated dominance of green algae and higher plants (lutein, chlorophyll-b and pheophytin-b) and chromophyte algae (diatoxanthin). Indicators of total algal biomass ( $\beta$-carotene, chlorophyll-a, pheophytins-a) showed no marked trend throughout the core. Profiles of green algae and higher plant pigments (lutein, chlorophyll-b, pheophytins-b) showed peak concentration at $14-16 \mathrm{~cm}$ and a decreasing trend towards the surface. Ordination of the pigments showed no discernible trends in the samples.

At SS86, located on the nunatak, marked changes in the pigment record occurred around 16-18 cm, with a shift from algal pigments to near complete dominance by bacterial chlorophyll-e (bchl-e) homologues specific to green sulfur bacteria (Figure 4c). Like the purple sulfur bacteria, green sulfur bacteria require photic zone anoxia to grow (Pfennig, 1989). This profile followed that of OC\% but with a small lag. Algal pigments exhibited relatively large variation down core with two peaks near the base of the core, a peak at 5-9 $\mathrm{cm}$ and a surface peak. Chromophyte-algal indicators (fucoxanthin, diatoxanthin, diadinoxanthin-like) dominated the record, but indicators of green algae (lutein, pheophytinb) were also an important component. Several common 

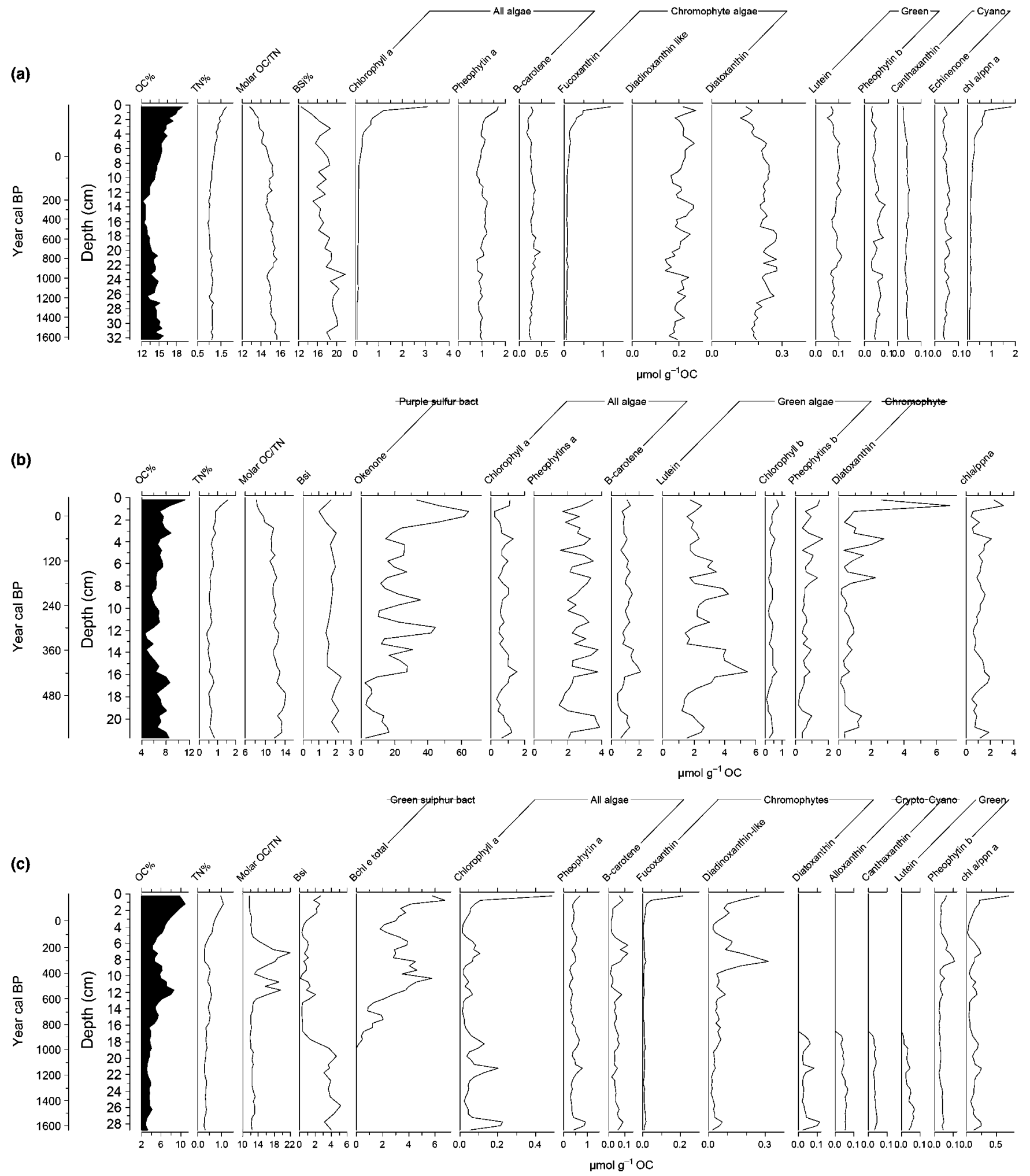

Figure 4. Sediment pigment record and geochemical proxies of the study lakes. Biogenic silica (BSi), organic carbon (OC), and total nitrogen (TN) presented as weight percentage, OC/TN as molar ratio. Chlorophylls (chlorophyll-a and b, pheophytins-a and b) and carotenoids (the remainder of the pigments) as concentration in $\mu \mathrm{mol} \mathrm{g}{ }^{-1} \mathrm{OC}$. The ratio of chl-a/ppn-a is included as a degradation signal. Note different scales on $x$-axis. (a) Coastal lake SS49. (b) Oligosaline lake SS1371, pheophytins-a and b include pheophytin and pyro-pheophytin as they are both important degradation products in this lake. (c) Nunatak lake SS86, Bchl-e total includes eight homologs of bacteriochlorophyll-e. 
algal and higher plant indicators (diatoxanthin, alloxanthin, canthaxanthin and lutein) disappeared or were masked by large amounts of bacterial pigments (bchl-e homologues) in the top half of the core. The preservation indicator showed periods of increased preservation coinciding with periods of maximum algal pigment concentration, for example, around 5-9 $\mathrm{cm}$ and at the core surface. Ordination of the pigments showed two distinct clusters representing the top- and bottom-half of the core.

\section{Stable $\delta^{15} \mathrm{~N}$ isotopes at SS49}

Stable isotope measurements from SS49 (Figure 5a) showed that prior to 1920 , sediment $\delta^{15} \mathrm{~N}$ measurements, although sparse, were stable around 1.3\%. Subsequently, $\delta^{15} \mathrm{~N}$ values declined by c. $1 \%$ o from c. 1920 , whilst organic $\mathrm{C}$ and total $\mathrm{N}$ content of sediment samples almost doubled (Figure 4a). OC/TN molar ratio exhibited a distinct decrease over the same period. The pigment PCA-1 scores followed the observed isotopic trend. The timing of the decline in the lake sediment

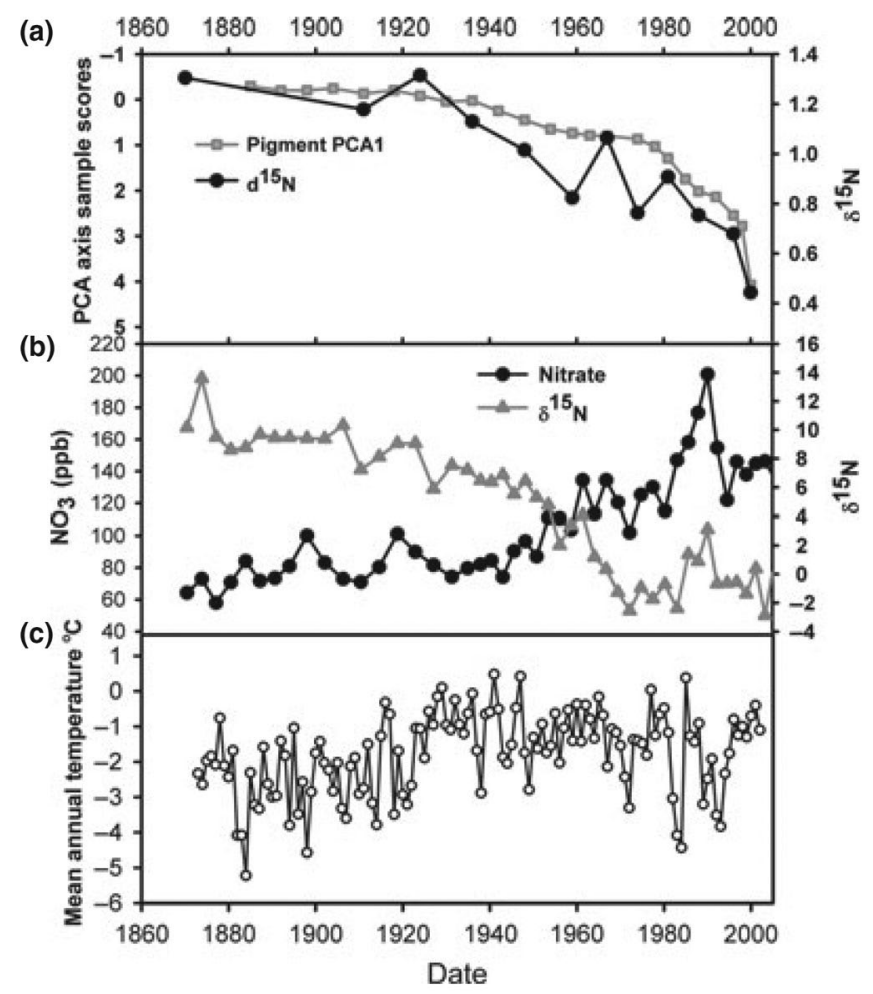

Figure 5. (a) $\delta^{15} \mathrm{~N}$ and pigment PCA-1 at SS49 plotted against ${ }^{210} \mathrm{~Pb}$ timescale; (b) $\delta^{15} \mathrm{~N}$ and $\mathrm{NO}_{3}$ in the Greenland ice core (Hastings et al., 2009); and (c) mean annual temperature at Nuuk (Cappelen, 2004), showing representative trends in air temperature for SW Greenland since 1860. proxies are in line with changes in $\mathrm{NO}_{3}{ }^{-}$and $\delta^{15} \mathrm{~N}$ (of $\mathrm{NO}_{3}{ }^{-}$) from the Greenland ice cores (Hastings, Jarvis \& Steig, 2009; Figure 5b) while no trend was observed in the temperature trends from Nuuk (Figure 5c).

\section{Discussion}

Changes in the phototrophic communities of three contrasting lakes in the Kangerlussuaq area, SW Greenland revealed very different responses to environmental change over the last 600-1600 years that are interpreted in relation to the E-m-flux model of Leavitt et al. (2009) (Figure 6). At SS1371 and SS86, the main driver has been variability of E-flux via effects on stratification and light availability for photosynthetic bacteria. At SS86, $m$-flux was also important historically, resulting in lake level lowering, creation of a closed-basin system and the development of chemical stratification. At SS49, $m$ and Efluxes were more constant as medium-term (decadal to centennial) climate variability reduced, although atmospheric nutrient loading may have increased (Figure 5). Our interpretations of the observed in-lake changes not only emphasize the varying importance of the mechanisms involved in transferring and filtering environmental forcing into ecological response by phototrophic communities but also that these relationships can themselves change over time.

\section{Mass flux: Precipitation}

The most pronounced impact of the reduced precipitation from around $800 \mathrm{cal}$. year BP on the study lakes was observed at the nunatak lake (SS86), where the pigment, carbon and BSi profiles indicate a switch from a freshwater, autotrophic lake to an increasingly chemolithotrophic system within a few decades around $1000 \mathrm{cal}$. year BP (Figure 4). This is concomitant with the latter part of the Medieval Climate Anomaly (Figure 6) and a lakelevel lowering, ultimately falling below the outlet level. This interpretation is consistent with studies of paleoshorelines in the area indicating that precipitation (and lake levels) decreased briefly prior to 1000 cal. year $\mathrm{BP}$ and then fell sharply to modern levels after c. 700 cal. year BP (Aebly \& Fritz, 2009). SS86 has a catchment too small to supply the lake with sufficient runoff to sustain an outflow during a period of negative precipitation balance. The role of lake:catchment ratios is exemplified by the neighboring lake SS32, an open basin with a larger catchment and an outflow resulting in different water chemistry characteristics (Anderson et al., 2001; Table 1) that have not undergone the dramatic switches seen at SS86 (Perren, Douglas \& Anderson, 2009). 


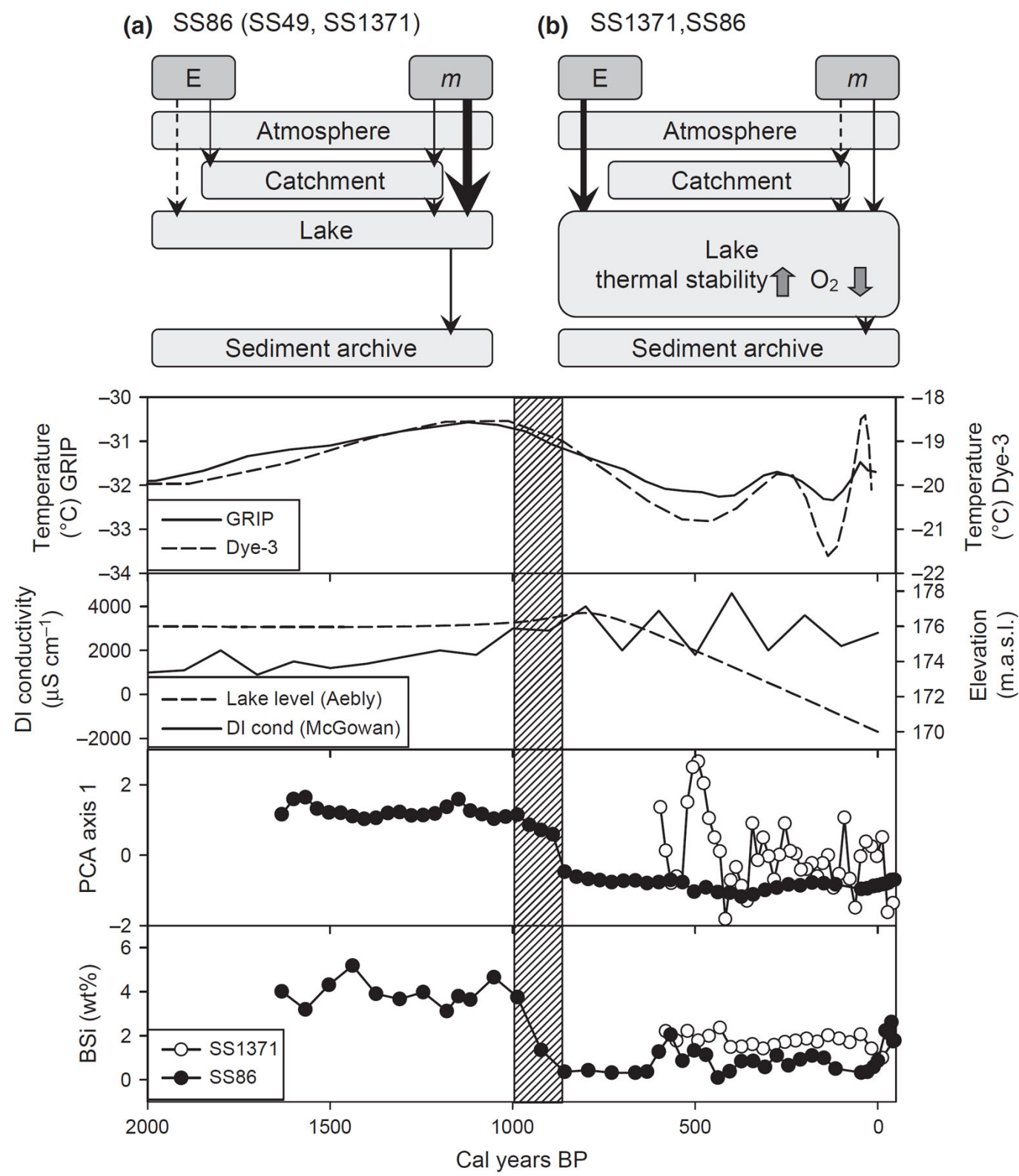

Figure 6. Conceptual interpretation of the relative importance of energy (E) and mass ( $m$ ) in controlling lake response (summarized by PCA-axis 1 and BSi) to environmental change according to Leavitt et al. (2009). While direct influx of $m$ through precipitation is inferred to exert a strong control on all lakes before $c .1000$ cal year BP (a), direct influx of E is inferred to have a greater influence in closed-basin systems (SS1371 and SS86 after c. 1000 cal year BP)(b). SS49 has not been included in the plot due to no change in the main controlling factor during the investigated time period. Supplementary paleolimnological proxies have been included for comparison; the temperature reconstruction from the Greenland GRIP and Dye-3 ice cores (Dahl-Jensen et al., 1998), regional lake-levels (Aebly \& Fritz, 2009), and diatom-inferred conductivity from SS4 (McGowan et al., 2003).

Closed-basin lakes are thought to be especially sensitive to climate change due to the tight coupling between water level and chemistry, forced by changes in temperature and effective precipitation (Fritz, 1996; Battarbee, 2000). However, the time period covered by the freeze core at SS1371 was too short to include the effect of the lake level lowering inferred for the area from c. 1000 cal. year BP. Nevertheless, the presence of fossil shorelines around the lake indicate that this site has indeed been subject to lake-level lowering and solute concentration as well as expansion of purple sulfur bacteria around $1000 \mathrm{cal}$. year BP as observed in other lakes (e.g. SS4) in the region (McGowan et al., 2008).

An unquantified but possibly important component of changing $m$-flux in the Kangerlussuaq area is the increased regional deposition of loess that accompanied 
increased aeolian activity during the neoglacial cooling (Willemse et al., 2003). The area between SS1371 and the present ice sheet margin (Figure 1) is subject to considerable aeolian input, sufficient to dilute the organic content of lake sediments particularly during the Little Ice Age (Anderson et al., 2012). The ecological effects of dust loading on remote lakes are well known due to their high nutrient content (Field et al., 2010). The input of loess in the Kangerlussuaq area has been shown to have had considerable impact on the biological communities of these lakes (Perren et al., 2012).

\section{Mass flux: Nutrient influx}

The coastal and dilute lake (SS49) showed few changes in algal community composition prior to c. $1900 \mathrm{AD}$ (50 cal. year BP) when pigment concentration increased (Figure 4). Primary production in oligotrophic arctic lakes is dominated by relatively stable benthic communities, which can contribute substantially (80-98\%) to the primary production (Vadeboncoeur et al., 2003). The inference of a substantial benthic community at SS49 is supported by the stratigraphic record with high concentrations of both chromophyte-algal pigments and BSi (the latter an order of magnitude higher than the other lakes, Figure 4), indicating the importance of diatoms. Pigment indicators of green algae, higher plants and cyanobacteria also most likely originate from a benthic community, based on contemporary regional lake surveys. Michelutti et al. (2005) reported increased production in a number of arctic lakes, which they attributed primarily to recent warming although increased nutrient availability is implicit. Oligotrophic lakes are sensitive to even small increases in nutrient input due to the very low initial content (Leavitt et al., 2009) and there is now increasing evidence of the ecological effects of $\mathrm{N}$ deposition at remote arctic and alpine lakes (Galloway et al., 2008; Holtgrieve et al., 2011). Deposition rates of NOx are not well prescribed for western Greenland, but are low $\left(<0.5 \mathrm{~kg} \mathrm{~N}\right.$ ha year $\left.{ }^{-1}\right)$ although loadings are presumably greater in coastal regions where precipitation is higher (Hasholt \& Søgaard, 1978).

The $\delta^{15} \mathrm{~N}$ data at SS49 represent a significant change in the $\mathrm{N}$ biogeochemistry of the lake initiated at the beginning of the 20th Century (Figure 5). The trend towards more depleted $\delta^{15} \mathrm{~N}$ values is comparable with those observed in other arctic and northern hemisphere mountain lakes (e.g. Wolfe, Edwards \& Aravena, 1999; Wolfe et al., 2003; Holtgrieve et al., 2011) and is consistent with increased inputs of anthropogenic $\mathrm{N}$ arising from fossil fuel combustion. Such anthropogenic sources are generally isotopically depleted in ${ }^{15} \mathrm{~N}$, and ice-core records from Greenland document a progressive change from preindustrial $\delta^{15} \mathrm{~N}$ values of $c$. $11 \%$ o to $c a .-1 \%$ in $\mathrm{NO}_{3}{ }^{-}$concomitant with a doubling in nitrate concentration in deposition during the 20th Century (Hastings et al., 2009; Figure 5). The agreement between $\delta^{15} \mathrm{~N}$, pigment PCA-1 and the increasing organic C content since c. 1880 is strongly supportive of a linear change in productivity in response to increased nutrient input.

Both the interpretation of $\delta^{15} \mathrm{~N}$ and PCA- 1 of the pigments can be affected by diagenesis (Leavitt, 1993; Talbot, 2001; Galman, Rydberg \& Bigler, 2009). However, at SS49 the sediment data are inconsistent with a diagenetic effect as the observed changes occurred over longer time frames (several decades) than expected with diagenesis. In general, pigments in the top 1-3 cm of lake sediments are interpreted as being affected by postdepositional degradation (Leavitt, 1993). Moreover, the anticipated isotopic effect of such processes would lead to an enrichment trend in $\delta^{15} \mathrm{~N}$ (Galman et al., 2009), the converse of that observed. Climate change in recent decades in combination with its effects on changes in the catchment could be posited as a cause for the observed $\delta^{15} \mathrm{~N}$ record. However, following statistical analysis of the meteorological data (Simpson, unpublished; Figure 5), no trend in 20th Century monthly mean temperature (at Nuuk) was observed, a local pattern that is consistent with temperature trends throughout SW Greenland (Box, 2002). Furthermore, the timing of recent Arctic warming is inconsistent with the observed change in $\delta^{15} \mathrm{~N}$ at this site.

Nitrogen accrual is an important process in arctic ecosystems largely associated with terrestrial vegetation succession and the role of N-fixation by Dryas spp. and Alnus sp. (Engstrom et al., 2000). However, changes of the in-lake $\mathrm{N}$ pool can also result from $\mathrm{N}$ fixation by cyanobacteria, which form extensive littoral mats in oligotrophic arctic lakes. The soil microbial and hydrological processes that can result in $\mathrm{N}$ transfer from land to water are complex and highly seasonal due to the relationships between N-mineralization, snow melt and plant uptake (Hobbie, Nadelhoffer \& Hogberg, 2002). Moreover, these processes are hypothesized to change with warming of the Arctic, but presumably this is not important in the Kangerlussuaq area given the relatively steady temperatures recorded for much of the 20th Century (Figure 5). The SS49 catchment is sparsely vegetated with thin soils, in contrast to inland catchments with more extensive shrub tundra and thicker soils. The greater precipitation at the coast, coupled with thin soils suggests that the sediment $\delta^{15} \mathrm{~N}$ profile of SS49 is reflecting direct deposi- 
tion of NOx on to the lake. Interestingly, $\delta^{15} \mathrm{~N}$ profiles from sediment cores from inland lakes do not show the characteristic depletion observed in many arctic lakes (Simpson, unpublished).

\section{Energy flux}

SS1371 showed considerable short-term variability but little directional changes in phototrophic community composition over time (Figure 4). The pigment record indicates input from higher plants and green algae, probably including input from the extensive Chara beds in the littoral zone, as well as chromophytes and the dominant phototrophic sulfur bacterial communities. The continuous dominance of phototrophic purple sulfur bacterial pigments suggests that the lake was meromictic or had prolonged periods of anoxic bottom water throughout the approximately 600 -year period covered by the core. Indicators of phototrophic sulfur bacteria often are observed in both saline and freshwater lakes where light penetrates to anoxic waters and have previously been used to infer major shifts in lake status (Leavitt, Carpenter \& Kitchell, 1989; Vinebrooke et al., 1998; Pienitz et al., 2000; Squier, Hodgson \& Keely, 2002; McGowan et al., 2008). The inference of meromictic conditions in the modern lake is supported by temperature thermistors deployed over 5 years at SS1371 (Anderson, unpublished). Strong stratification and good light transparency could promote the highfrequency variability in community structure, due to tight coupling between stratification and the phototrophic community (e.g. Pfennig, 1989; Vila et al., 1998). While the continued negative precipitation balance and resulting decreasing lake level inferred from fossil shorelines (Aebly \& Fritz, 2009) over the last c. 1000 years is the primary cause of the establishment of closed-basin systems in the area, it cannot explain the observed variability of the phototrophic community. On the other hand, considerable change in temperature has been inferred from the ice cores during this period (Dahl-Jensen et al., 1998) and direct E-flux is therefore inferred as the primary controlling mechanism of the lake response (Figure 6).

At the nunatak lake (SS86), dominance of green sulfur bacterial pigments in the upper half of the sediment core (Figure 4) also indicate chemical stratification and light penetration into an anoxic hypolimnion (Pfennig, 1989). The observed changes in the phototrophic community and geochemical markers suggest a transition from a dilute, oligotrophic lake to one with stronger seasonal chemical stratification, hypolimnic anoxia, and substantial phototrophic bacterial production over the last $c .1000$ years. A change in the main controlling mechanism of this lake from direct mass (precipitation) to energy (Figure 6) is inferred in accordance with interpretations of trends at the other lakes in this study.

\section{Synthesis}

Changes in the phototrophic community in the southwest Greenland lakes are driven by a combination of factors, including direct and indirect $\mathrm{E}$ and $m$ forcing (e.g. radiative forcing, temperature, effective precipitation, ice-free period), mediated by location, catchment/lake ratios, and in-lake processes (e.g. stratification). Although precipitation levels are low in much of the Arctic, with associated reduced hydrological fluxes from land to lake, catchment processes are still important and will mediate $m$-flux to the lake. For example, Anderson et al. (2008) found significant effects on biological structure associated with the arrival of Betula nana in SW Greenland through sequestration of nutrients. Any assessment of 'drivers' of limnological change in the Arctic should include a terrestrial/vegetation component (Wookey et al., 2009) but conceptual models that have been developed to account for recent biological change at high latitudes have tended to downplay alternative hypotheses such as catchment processes (Smol \& Douglas, 2007). Moreover, as well as changing $\mathrm{E}$ and $m$-fluxes, in-lake processes (altered trophic interactions, benthic-pelagic coupling) and other ontogenetic processes (long-term accumulation of salts, dissolved organic carbon) may have considerable influence on biological structure independent of climate (Anderson et al., 2004), therefore making it difficult to infer climate unambiguously from biological remains in lake sediments (Lotter \& Birks, 2003). The contrasting responses of the three lakes in this study to global environmental change processes over the last $c .1600$ years highlights the need to consider greater regional variability as we attempt to disentangle the ecological response of arctic lakes to multiple stressors. This is true even in a relatively small area $(<150 \mathrm{~km})$ such as the Kangerlussuaq lake district, which is reasonably homogenous in terms of geology and vegetation. As highlighted by Kaufman (2012), recognizing the spatial complexity of lake responses to regional climate forcing and the associated non-climatic filters is critical if lake sediment records are to be used to reconstruct past-climate variability in the Arctic. There is clearly a need for greater replication at the regional scale to help identify signals of environmental change. 
Acknowledgments - We are grateful to I. Renberg during coring and subsampling of the cores, B. Perren for help during subsampling, and B. Møller for assistance in the laboratory. We also thank P. Appleby for conducting the ${ }^{210} \mathrm{~Pb}$ dating. A. Lami and R. Cox kindly provided standards of purple and green sulfur bacteria, respectively. L. Schlüter provided assistance for separation of bacterial pigments from culture. Funding for field collection of cores and dating was provided by a U.S. NSF grant (ATM-0081226) to S. Fritz. Additional fieldwork and analysis were funded by grants from the Danish Natural Science Research Council (SNF 21-02-0390 and SNF 51-00-0288) to N. J. Anderson and a STENO-grant from The Danish Council for Independent Research - Natural Sciences (FNU) to N. S. Reuss (09-064952).

\section{References}

Aebly F. A. \& Fritz S. C. (2009) Palaeohydrology of Kangerlussuaq (Sondre Stromfjord), West Greenland during the last $\sim 8000$ years. The Holocene, 19, 91-104.

Anderson N. J., Brodersen K. P., Ryves D. B., McGowan S., Johansson L. S., Jeppesen E. et al. (2008) Climate versus inlake processes as controls on the development of community structure in a low-arctic lake (South-West Greenland). Ecosystems, 11, 307-324.

Anderson N. J., Harriman R., Ryves D. B. \& Patrick S. T. (2001) Dominant factors controlling variability in the ionic composition of West Greenland Lakes. Arctic Antarctic and Alpine Research, 33, 418-425.

Anderson N. J., Liverside A. C., McGowan S. \& Jones M. D. (2012) Lake and catchment response to Holocene environmental change: Spatial variability along a climate gradient in southwest Greenland. Journal of Paleolimnology, 48, 209- 222.

Anderson N. J., Ryves D. B., Grauert M. \& McGowan S. (2004) Holocene paleolimnology of Greenland and the north Atlantic islands (north of $60^{\circ} \mathrm{N}$ ). In: Long-Term Environmental Change in Arctic and Antarctic Lakes (eds. R. Pienitz, M. S. V. Douglas, \& J. P. Smol), pp. 319-347. Springer, the Netherlands.

Anderson N. J. \& Stedmon C. A. (2007) The effect of evapoconcentration on dissolved organic carbon concentration and quality in lakes of SW Greenland. Freshwater Biology, $52,280-289$.

Appleby P. G. (2001) Chronostratigraphic techniques in recent sediments. In: Tracking Environmental Change Using Lake Sediments, Basin Analysis, Coring, and Chronological Techniques, vol. 1 (eds. W. M. Last \& J. P. Smol), pp. 171-203, Kluwer Academic Publishers, Dordrecht.

Appleby P. G., Nolan P. J., Gifford D. W., Godfrey M. J., Oldfield F., Anderson N. J. et al. (1986) Pb-210 dating by low background gamma-counting. Hydrobiologia, 143, 21-27.

Appleby P. G. \& Oldfield F. (1978) The calculation of $210 \mathrm{~Pb}$ dates assuming a constant rate of supply of unsupported $210 \mathrm{~Pb}$ to the sediment. Catena, 5, 1-8.
Battarbee R. W. (2000) Palaeolimnological approaches to climate change, with special regard to the biological record. Quaternary Science Reviews, 19, 107-124.

Bergström A. K., Blomqvist P. \& Jansson M. (2005) Effects of atmospheric nitrogen deposition on nutrient limitation and phytoplankton biomass in unproductive Swedish lakes. Limnology and Oceanography, 50, 987-994.

Bindler R., Renberg I., Anderson N. J., Appleby P. G., Emteryd O. \& Boyle J. (2001) Pb isotope ratios of lake sediments in West Greenland: Inferences on pollution sources. Atmospheric Environment, 35, 4675-4685.

Bonilla S., Villeneuve V. \& Vincent W. F. (2005) Benthic and planktonic algal communities in a High Arctic Lake: Pigment structure and contrasting responses to nutrient enrichment. Journal of Phycology, 41, 1120-1130.

Box J. E. (2002) Survey of Greenland instrumental temperature records: 1873-2001. International Journal of Climatology, 22, 1829-1847.

Burton H. R. (1981) Chemistry, physics and evolution of antarctic saline lakes - A review. Hydrobiologia, 81, 339-362.

Cappelen J. (2004) Yearly mean temperature for selected meteorological stations in Denmark, the Farroe Islands and Greenland; 1873-2003. Technical report 0407. Danish Meteorological Institute, Copenhagen.

Conley D. J. (1998) An interlaboratory comparison for the measurement of biogenic silica in sediments. Marine Chemistry, 63, 39-48.

Conley D. J. \& Schelske C. L. (2001) Biogenic silica. In: Tracking Environmental Change Using Lake Sediments. Volume 3: Terrestrial, Algal, and Siliceous Indicators (eds. J. P. Smol, H. J. B. Birks, \& W. M. Last), pp. 281-293. Kluwer Academic Publishers, Dordrecht.

Dahl-Jensen D., Mosegaard K., Gundestrup N., Clow G. D., Johnsen S. J., Hansen A. W. et al. (1998) Past temperatures directly from the Greenland Ice Sheet. Science, 282, 268-271.

D’Andrea W. J., Huang Y., Fritz S. C. \& Anderson N. J. (2011) Abrupt Holocene climate change as an important factor for human migration in West Greenland. Proceedings of the National Academy of Sciences of the USA, 108, 9765-9769.

DeMaster D. J. (1981) The supply and accumulation of silica in the marine environment. Geochimica et Cosmochimica Acta, 45, 1715-1732.

Engstrom D. R., Fritz S. C., Almendinger J. E. \& Juggins S. (2000) Chemical and biological trends during lake evolution in recently deglaciated terrain. Nature, 408, 161-166.

Field J. P., Belnap J., Breshears D. D., Neff J. C., Okin G. S., Whicker J. J. et al. (2010) The ecology of dust. Frontiers in Ecology and the Environment, 8, 423-430.

Frigaard N. U., Larsen K. L. \& Cox R. P. (1996) Spectrochromatography of photosynthetic pigments as a fingerprinting technique for microbial phototrophs. FEMS Microbiology Ecology, 20, 69-77.

Fritz S. C. (1996) Paleolimnological records of climatic change in North America. Limnology and Oceanography, 41, 882-889. 
Galloway J. N., Townsend A. R., Erisman J. W., Bekunda M., Cai Z., Freney J. R. et al. (2008) Transformation of the nitrogen cycle: Recent trends, questions, and potential solutions. Science, 320, 889-892.

Galman V., Rydberg J. \& Bigler C. (2009) Decadal diagenetic effects on $\delta^{13} \mathrm{C}$ and $\delta^{15} \mathrm{~N}$ studied in varved lake sediment. Limnology and Oceanography, 54, 917-924.

Hasholt B. \& Søgaard H. (1978) Et forsøg på en klimatiskhydrologisk regionsinddeling af Holsteinsborg kommune (Sisimiut). Geografisk Tidsskrift, 77, 72-92.

Hastings M., Jarvis J. \& Steig E. (2009) Anthropogenic Impacts on Nitrogen Isotopes of Ice-Core Nitrate. Science, 324, 1288.

Heggen M. P., Birks H. H. \& Anderson N. (2010) Long-term ecosystem dynamics of a small lake and its catchment in west Greenland. Holocene, 20, 1207-1222.

Hobbie S. E., Nadelhoffer K. J. \& Hogberg P. (2002) A synthesis: The role of nutrients as constraints on carbon balances in boreal and arctic regions. Plant and Soil, 242, 163-170.

Holtgrieve G. W., Schindler D. E., Hobbs W. O., Leavitt P. R., Ward E. J., Bunting L. et al. (2011) A Coherent Signature of Anthropogenic Nitrogen Deposition to Remote Watersheds of the Northern Hemisphere. Science, 334, 1545-1548.

Jeffrey S. W., Mantoura R. F. C. \& Wright S. W. (1997) Phytoplankton Pigments in Oceanography. UNESCO Publishing, Paris.

Kane D. L., Hinzman L. D., Woo M. \& Everett K. R. (1992) Arctic hydrology and climate change. In: Arctic Ecosystems in A Changing Climate (eds. F. S. Chapin, R. L. Jefferies, J. F. Reynolds, G. R. Shaver, J. Svoboda \& E. W. Chu), pp. 3557. Academic Press, Inc., San Diego, CA.

Kaufman D. S. (2012) Introduction to the special issue, "Holocene paleoenvironmental records from Arctic lake sediment." Journal of Paleolimnology, 48, 1-7.

Leavitt P. R. (1993) A review of factors that regulate carotenoid and chlorophyll deposition and fossil pigment abundance. Journal of Paleolimnology, 9, 109-127.

Leavitt P. R., Carpenter S. R. \& Kitchell J. F. (1989) Whole-lake experiments: The annual record of fossil pigments and zooplankton. Limnology and Oceanography, 34, 700-717.

Leavitt P. R., Findlay D. L., Hall R. I. \& Smol J. P. (1999) Algal responses to dissolved organic carbon loss and $\mathrm{pH}$ decline during whole-lake acidification: evidence from paleolimnology. Limnology and Oceanography, 44, 757-773.

Leavitt P. R., Fritz S. C., Anderson N. J., Baker P. A., Blenckner T., Bunting L. et al. (2009) Paleolimnological evidence of the effects on lakes of energy and mass transfer from climate and humans. Limnology and Oceanography, 54, 2330-2348.

Leavitt P. R. \& Hodgson D. A. (2001) Sedimentary pigments. In: Tracking Environmental Change Using Lake Sediments. Volume 3: Terrestrial, Algal, and Siliceous Indicators (eds. J. P. Smol, H. J. B. Birks \& W. M. Last), pp. 295-325. Kluwer Academic Publishers, Dordrecht, The Netherlands.

Lotter A. F. \& Birks H. J. B. (2003) The Holocene palaeolimnology of Sagistalsee and its environmental history - A synthesis. Journal of Paleolimnology, 30, 333-342.
McGowan S., Juhler R. K. \& Anderson N. J. (2008) Autotrophic response to lake age, conductivity and temperature in two West Greenland lakes. Journal of Paleolimnology, 39, 301- 317.

McGowan S., Ryves D. B. \& Anderson N. J. (2003) Holocene records of effective precipitation in West Greenland. The Holocene, 13, 239-249.

Michelutti N., Wolfe A. P., Vinebrooke R. D., Rivard B. \& Briner J. P. (2005) Recent primary production increases in arctic lakes. Geophysical Research Letters, 32, L19715. doi: 10.1029/2005GL023693.

Ouellet M., Bisson M., Page P. \& Dickman M. (1987) Physicochemical limnology of meromictic saline Lake Sophia, Canadian arctic archipelago. Arctic and Alpine Research, 19, 305-312.

Overpeck J., Hughen K., Hardy D., Bradley R., Case R., Douglas M. et al. (1997) Arctic environmental change of the last four centuries. Science, 278, 1251-1256.

Perren B. B., Anderson N. J., Douglas M. S. V. \& Fritz S. (2012) The influence of temperature, moisture, and eolian activity on Holocene lake development in West Greenland. Journal of Paleolimnology, 48, 223-239.

Perren B. B., Douglas M. S. V. \& Anderson N. J. (2009) Diatoms reveal complex spatial and temporal patterns of recent limnological change in West Greenland. Journal of Paleolimnology, 42, 233-247.

Pfennig N. (1989) Ecology of phototrophic purple and green sulfur bacteria. In: Autotrophic Bacteria (eds. H. G. Schlegel \& B. Bowien), pp. 97-116. Science Tech Publ., Madison, WI.

Pienitz R., Smol J. P., Last W. M., Leavitt P. R. \& Cumming B. F. (2000) Multi-proxy Holocene palaeoclimatic record from a saline lake in the Canadian Subarctic. The Holocene, 10, 673- 686.

Pla S. \& Anderson N. J. (2005) Environmental factors correlated with chrysophyte cyst assemblages in low arctic lakes of southwest Greenland. Journal of Phycology, 41, 957-974.

Post E., Forchhammer M. C., Bret-Harte M. S., Callaghan T. V., Christensen T. R., Elberling B. et al. (2009) Ecological dynamics across the Arctic associated with recent climate change. Science, 325, 1355-1358.

Quinlan R., Douglas M. S. V. \& Smol J. P. (2005) Food web changes in arctic ecosystems related to climate warming. Global Change Biology, 11, 1381-1386.

Reuss N. \& Conley D. J. (2005) Effects of sediment storage conditions on pigment analyses. Limnology and OceanographyMethods, 3, 477-487.

Reuss N., Hammarlund D., Rundgren M., Segerström U., Eriksson L. \& Rosén P. (2010a) Lake Ecosystem Responses to Holocene Climate Change at the Subarctic Tree-Line in Northern Sweden. Ecosystems, 13, 393-409.

Reuss N., Leavitt P., Hall R., Bigler C. \& Hammarlund D. (2010b) Development and application of sedimentary pigments for assessing effects of climatic and environmental changes on subarctic lakes in northern Sweden. Journal of Paleolimnology, 43, 149-169. 
Smol J. P. \& Douglas M. S. V. (2007) From controversy to consensus: making the case for recent climate change in the Arctic using lake sediments. Frontiers in Ecology and the Environment, 5, 466-474.

Smol J. P., Wolfe A. P., Birks H. J. B., Douglas M. S. V., Jones V. J., Korhola A. et al. (2005) Climate-driven regime shifts in the biological communities of arctic lakes. Proceedings of the National Academy of Sciences of the United States of America, 102, 4397-4402.

Squier A. H., Hodgson D. A. \& Keely B. J. (2002) Sedimentary pigments as markers for environmental change in an Antarctic lake. Organic Geochemistry, 33, 1655-1665.

Talbot M. R. (2001) Nitrogen isotopes in palaeolimnology. In: Tracking Environmental Change Using Lake Sediments. Volume 2: Physical and Geochemical Methods (eds. W. M. Last \& J. P. Smol), pp. 401-439, Kluwer Academic Publishers, Dordrecht, The Netherlands.

Vadeboncoeur Y., Jeppesen E., Vander Zanden M. J., Schierup H. H., Christoffersen K. \& Lodge D. M. (2003) From Greenland to green lakes: Cultural eutrophication and the loss of benthic pathways in lakes. Limnology and Oceanography, 48, 1408-1418.

Vila X., Abella C. A., Figueras J. B. \& Hurley J. P. (1998) Vertical models of phototrophic bacterial distribution in the metalimnetic microbial communities of several freshwater North-American kettle lakes. FEMS Microbiology Ecology, 25, 287-299.

Vincent W. F., Hobbie J. E. \& Laybourn-Parry J. (2008) Introduction to the limnology of high-latitude lake and river ecosystems. In: Polar Lakes and Rivers (eds. W. F. Vincent \& J. Laybourn-Parry), pp. 1-24. Oxford University Press, New York.

Vinebrooke R. D., Hall R. I., Leavitt P. R. \& Cumming B. F. (1998) Fossil pigments as indicators of phototrophic response to salinity and climatic change in lakes of western Canada. Canadian Journal of Fisheries and Aquatic Sciences, $55,668-681$.
Willemse N. W., Koster E. A., Hoogakker B. \& van Tatenhove F. G. M. (2003) A continuous record of Holocene eolian activity in West Greenland. Quaternary Research, 59, 322-334.

Willemse N. W., van Dam O., van Helvoort P. J., Dankers R., Brommer M., Schokker J. et al. (2004) Physical and chemical limnology of a subsaline athalassic lake in West Greenland. Hydrobiologia, 524, 167-192.

Williams W. D. (1991) Comments on the so-called salt lakes of Greenland. Hydrobiologia, 210, 67-74.

Wolfe A. P., Cooke C. A. \& Hobbs W. O. (2006) Are current rates of atmospheric nitrogen deposition influencing lakes in the Eastern Canadian Arctic? Arctic Antarctic and Alpine Research, 38, 465-476.

Wolfe B. B., Edwards T. W. D. \& Aravena R. (1999) Changes in carbon and nitrogen cycling during tree-line retreat recorded in the isotopic content of lacustrine organic matter, western Taimyr Peninsula, Russia. The Holocene, 9, 215-222.

Wolfe B. B., Edwards T. W. D., Jiang H., MacDonald G. M., Gervais B. R. \& Snyder J. A. (2003) Effect of varying oceanicity on early- to mid-Holocene palaeohydrology, Kola Peninsula, Russia: isotopic evidence from treeline lakes. The Holocene, 13, 153-160.

Wookey P. A., Aerts R., Bardgett R. D., Baptist F., Brathen K. A., Cornelissen J. H. C. et al. (2009) Ecosystem feedbacks and cascade processes: Understanding their role in the responses of Arctic and alpine ecosystems to environmental change. Global Change Biology, 15, 1153-1172.

Wright S. W., Jeffrey S. W., Mantoura R. F. C., Llewellyn C. A., Bjørnland T., Repeta D. et al. (1991) Improved HPLC method for the analysis of chlorophylls and carotenoids from marine phytoplankton. Marine Ecology Progress Series, 77, 183-196.

Züllig H. (1985) Pigmente phototropher Bakterien in Seesedimenten und ihre Bedeutung für die Seenforschung. Schweizerische Zeitschrift für Hydrologie, 47, 87-126. 